\title{
Sustainability in the hospitality industry in the shadow of the COVID-19 pandemic: a case study of the hospitality industry in Poland
}

\author{
Pawet Dahlke ${ }^{1}$, Katarzyna Orfin-Tomaszewska ${ }^{1 *}$, and Piotr Sosnowski ${ }^{1}$ \\ ${ }^{1}$ Stanislw Staszic State University of Applied Sciences in Pila, Economics Department, 64920 Piła, \\ Poland
}

\begin{abstract}
The article aims to discuss the implementation of the sustainable development goals on the example of Polish hotels in the light of the COVID-19 pandemic. Due to national and international restrictions and limitations, and, consequently, the inability of hotel facilities to operate in full capacity, it was important and legitimate for the authors to look at how the facilities achieved their own goals and how they corresponded with the assumptions of sustainable development in this difficult time. The article is based on case studies and practical experience of one of the authors. The data comes from secondary and primary sources, including: a survey conducted among 102 hotel facilities in Poland (CAWI method) and a case study of a chain hotel. The data was analysed in an exploratory and descriptive manner. A significant contribution is the original approach to interpreting the market situation in the Polish hospitality industry and an attempt to indicate the direction in which it will develop. The most important conclusions include the fact that many of the tasks and initiatives carried out by the observed facilities are part of the UN SDGs, and the situation during the pandemic influenced their temporal limitation or was not relevant for them. The conducted research made it possible to clearly indicate specific recommendations for the further development of hotel facilities in accordance with the sustainable development concept.
\end{abstract}

Keywords: sustainability, hospitality industry, COVID-19, pandemic

\section{Introduction}

The impact of the COVID-19 pandemic is the subject of many studies in every field of science and all markets. The effects of the pandemic are felt in almost all industries, with tourism considered one of the most severely affected. The article fills the theoretical and practical gap by proposing how to implement the principles of sustainable hospitality in the light of the COVID-19 pandemic, which are aimed at implementing the United Nations Sustainable Development Goals (SDGs). The value of this study lies in the fact that it draws from many original case studies, each of which is unique in its kind, and proposes innovative

* Corresponding author: korfin@puss.pila.pl 
ideas on how, in the shadow of the pandemic, the tourism and hospitality industry can implement SDGs in its operations while protecting the interests of the economy, society and the environment.

Since the industrial revolution, mankind has made remarkable technological achievements. Traveling is now possible not only around the globe, but also more and more often beyond the Earth's atmosphere. In developed countries, the overwhelming supply of consumer goods reassures consumers that they are independent of nature. Unfortunately, or maybe fortunately, in recent years nature has been increasingly reminding people that this is not the case. The thing that scientists dealing with the natural environment have been convinced for many years ceases to be secret lore and becomes common knowledge due to numerous climate changes, and as a result - the more and more frequent disasters that affect the inhabitants of places once free from these types of phenomena. Hence, the concept of sustainability in regard to the development of societies is becoming more and more often a challenge for many countries, economies, markets, companies and consumers. An increasing number of initiatives, actions and, importantly, comprehensive strategies are created to preserve the current resources for future generations.

The authors decided to focus on the activities that were carried out on the tourist market, and more precisely in the hospitality industry, as part of the sustainable development concept before and during the COVID-19 pandemic. Moreover, an attempt was made to determine the direction in which these activities will go in the future.

\section{Sustainability in hospitality industry: the literature review}

There is a growing belief in societies that without introducing appropriate changes in consumption habits, it will not be possible to stop the degradation of the natural environment. This striving for development while respecting, inter alia, the environment, is part of the sustainable development concept.

A well-known definition, presented in the Brundtland Report, defines sustainable development as one that meets the needs of the present without compromising the ability of future generations to meet their own needs [1]. This definition emphasizes the long-term aspect of the concept of sustainable development and introduces the ethical principle of achieving equality between present and future generations [2].

According to the concept of sustainable development, economic growth should lead to increasing social cohesion (including reducing social stratification, equalizing opportunities, counteracting marginalization and discrimination) and improving the quality of the natural environment, e.g., by limiting the harmful impact of production and consumption on the state of the environment and the protection of natural resources [3]. This concept has evolved considerably over the last several years.

As one of the first concepts, it was very general and distinguished three main aspects ecological, economic and social. Whereas today, in accordance with the 2030 Agenda for Sustainable Development [4] it contains 17 Sustainable Development Goals and 169 specific tasks that should be achieved by the world by 2030 . These tasks concern achievements in 5 areas - the so-called 5xP: people, planet, prosperity, peace, partnership. These goals are comprehensive and cover a very wide range of challenges, such as hunger, poverty, education, health, climate change, sustainable development, peace, social justice and gender equality [4].

Due to the increased attention of consumers, companies have been also, in a way, forced to intensify their efforts for sustainable development. This situation is particularly true for the tourism industry, as sustainable development has, in many ways, become a fundamental principle of tourism [6]. One of the reasons for this is the significant development of the tourism industry in recent decades. In addition to the positive effects of the said development, 
such as generating economic growth in target areas, negative effects that have a huge impact on the environment, culture, politics, society and economy are also generated [7].

In the tourism and hospitality industry, there can be observed a continuous increase in the number of customers who, when making their decisions, take into account the issues related to broadly understood sustainable development [8-12]. This is because customers who want to express their support for environmental protection choose hotels that declare themselves green, i.e., environmentally friendly $[13,14]$. The growing need for sustainable development also results from greater knowledge and concerns about the impact on tourism and the environment in general [7]. Today, tourism is an important economic factor in the green economy, therefore, it should be treated as an initiator of green procurement ${ }^{\dagger}$ and recognized as an important element of responsible consumption [15,16].

Hotels are very susceptible to external factors and pressures in the global world [17], while hotel operations as an important element of the tourism sector may contribute to environmental degradation [18]. To prevent this, many facilities in the hospitality industry are trying to implement low-emission energy technologies to meet environmental requirements and reduce the cost of carbon dioxide concentration in the atmosphere [19]. However, it should be borne in mind that these are cost-intensive activities and not all entities in the industry have adequate resources to carry out such investments.

The activity of the hospitality industry has enormous potential for introducing and developing tools, activities and instruments that stimulate sustainable tourism practice, thus offering a change in the socio-environmental scenery of the tourism sector's responsibility [20]. Unfortunately, a dozen or so years ago, the environmental friendliness of hospitality industry companies in many cases was limited to their claim that they were ecological, with their only activity in this regard being a display of information that the hotel was green [21], [22]. For many hotels, being an environmentally friendly facility is limited to simple practices, such as throwing away disposable toiletry containers from guest toilets, changing bed linen and towels less frequently or at a guest's request. Unfortunately, it is not uncommon for hoteliers to join commercial green marketing associations that advertise green hotels for a fee. Many of them grant various types of eco certificates and membership in their associations, aimed at asserting the client that they use an environmentally friendly facility, without reliable certification or checking the references of entities applying for membership [23]. This is a particularly undesirable phenomenon, as green certificates are a kind of guide for consumers, i.e. tourists, helping them make decisions about their expenses by indicating responsible service providers whose business activities are in line with the sustainable development of tourism [24-26].

Although most environmental initiatives only require organizational measures, hotels often involve both employees and guests in the environmental management process. An example of such actions are signs common in hotels reminding guests to turn off the lights, reuse towels or bedding, or use water more efficiently. In almost all cases, these tips are accompanied by information on care for the environment. While these practices tend to be environmentally friendly, it is fair to say that hotels largely benefit from savings, which is an obvious, but not always openly disclosed fact. An example of this practice is a sign that tells hotel guests "save the planet: reuse towels, save water", giving the impression that the hotel cares about saving water, when in fact it is merely an attempt to reduce the cost of laundry [27],[12]). Research conducted in 2018 in the area of implementing the idea of sustainable development in Polish hotels indicated mainly economic-environmental activities in the field of saving water, energy, materials, and the use of local products, while less frequently, in the opinion of the respondents - social or marketing aspects [28].

\footnotetext{
${ }^{\dagger}$ Widely understood as environmentally and socially friendly and economical at the same time.
} 
Nowadays, the tourism industry is undergoing enormous transformations, mainly due to the influence of new technologies on its concept, as well as various impacts and pressures that the growth of tourism causes is different [29]. Moreover, this sector is dependent on global trends in the tourism market, influencing both the type of products sought and the further directions of sustainable tourism development. Therefore, according to Trisic et al [6] entrepreneurs who want to succeed in this industry should take into account the increased demand for preserving the natural environment, good transport connections, infrastructure built in harmony with the natural environment, as well as the sustainable development of tourist destinations. Research carried out in 2017 by Kapera and Wszendybył-Sulska [30] indicated that over $60 \%$ of hotel guests believe that hotels should carry out environmentfriendly activities, which has a direct impact on nature protection, and is also related to reducing operating costs and creating a positive image of the facility.

This sustainable development approach is especially important during the pandemic, when the spread of the COVID-19 virus and large-scale travel restrictions are wreaking havoc on the tourism and hospitality industry around the world. According to an open letter from Gloria Guevara, President and CEO of the World Travel and Tourism Council, 50 million jobs worldwide are at risk due to the pandemic [31]. The COVID-19 pandemic has dealt serious blows to hoteliers around the world, as hotels are particularly vulnerable to reduced tourist traffic, and since events around the world are still being cancelled or postponed, hotel occupancy rates are constantly declining [32], [33].

\section{Materials and Methods}

Observing the tourism sector, including the hospitality industry, during the ongoing COVID19 pandemic is extremely difficult and interesting at the same time. The resulting situation, including national and international restrictions, had a direct impact on the functioning of accommodation facilities. Through the desk research method, including an in-depth analysis of the literature on the subject regarding sustainable development, but also the impact of COVID-19 on the hospitality industry, case studies, own observation and survey research among Polish accommodation establishments, the authors made an attempt to interpret the actions taken during the pandemic in the light of the 17 UN Sustainable Development Goals. The CAWI survey was conducted in the first quarter of 2021 among 102 hotels in Poland.

The considerations are exploratory and constitute the basis for undertaking wider research and the use of additional analytical research methods in the future. A valuable contribution of the article is original, scientific and industry observations, discussion and objective conclusions resulting from it.

The Polish hospitality industry has been severely affected by the effects of the pandemic, in particular due to government restrictions on the operation of facilities, the movement of people, as well as guests' concerns about traveling (for private or business purposes). As shown in the BOŚ Industry Report [34], according to Statistics Poland, 17.8 million tourists visited all accommodation facilities in Poland in 2020, which constituted almost a half of the number of tourists from the previous year. The financial result of the hotel sector in Poland in 2021 is forecast in terms of negative values [34]. The negative effects of the pandemic that describe the current situation in the hospitality industry include [34]:

- administrative restrictions that have been imposed on the operation of hotels and other accommodation facilities for more than one and a half years,

- temporary restrictions in the field of international tourism (e.g., border closure, a compulsory quarantine),

- a decrease in individual and business demand (e.g., due to fear of infection, restrictions on business travel, lack of family events, etc.), 
- "freezing" of the MICE segment, with no possibility or restrictions in regards to the organization of various types of fairs, conferences, company trips, trainings,

- restrictions on hotel gastronomy (85\% of facilities indicated that in 2020 the decline in revenues from gastronomy was higher than $40 \%$ yoy, and in the case of as many as $38 \%$ of hotels this decrease exceeded $80 \%$ ),

- low occupancy (in April and May 2020, an occupancy rate below 30\% was declared by $75 \%$ of hotels, while from November 2020 to January 2021, an occupancy rate below $20 \%$ was declared by nearly $90 \%$ of hotels),

- complete, temporary closure of accommodation facilities (in April 2021, 37\% of hotels were fully closed, i.e., three times more than in February).

As the discussed report indicates, the coronavirus pandemic and its consequences have led to an unprecedented financial performance deterioration in the accommodation sector. According to the report [34], total revenues in the companies employing more than 9 people in 2020 decreased by over $45 \%$ yoy, as compared to an average increase of $9 \%$ yoy in the previous 5 years. In 2020, only every fourth accommodation facility was profitable, while in the period before the pandemic, these entities accounted for $70-75 \%$. In the second quarter of 2020, aid instruments were introduced in Poland such as government and anti-crisis measures, aimed at mitigating the negative financial effects of the pandemic in the accommodation industry. Although many entities took advantage of the offered forms of support [35], without the possibility of fully functioning, these measures were described as insufficient. As indicated by the Chamber of Commerce of the Polish Hotel Industry in 2020, about $40 \%$ of employees in the industry lost their jobs in 2020 [37]. These people were forced to look for another form of employment, which resulted in their failure to return in 2021, hence more than a half of the hoteliers surveyed by the Chamber of Commerce [36] have problems with assembling a full team of employees.

As it results from own research, the respondents clearly indicated that the support under the so-called crisis shields was insufficient or definitely insufficient (88\%). Only $10 \%$ of the respondents indicated that it was rather sufficient, only partially (Figure 1). Although the Polish government estimates that the total value of the support offered under the Anti-Crisis Shield and the Financial Shield will amount to over PLN 312 billion (Anti-Crisis Shield Anti-Crisis Shield - Gov.pl portal, 2021), these values are still insufficient.

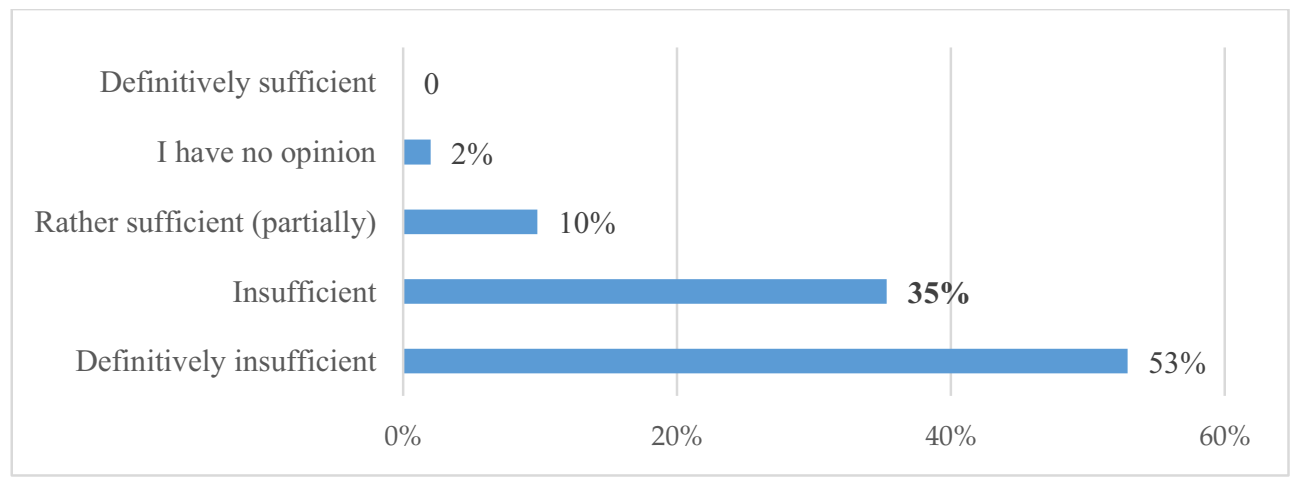

Fig. 1. Assessment of the respondents as to the forms of government and anti-crisis support offered in Poland during the pandemic (2020-2021).

In the commentary to the question asked, the respondents indicated that only lifting of the restrictions and the possibility of operating on the market would be the best chance to improve their financial situation. The more so because $88 \%$ of respondents indicated that they were able to create safe sanitary conditions in the facility. Moreover, the pandemic was 
an impulse to introduce various types of solutions in many areas of hotel activity (Figure 2), which were aimed at, inter alia, increasing security in the facility (guests and employees), generating savings, saving jobs, maintaining contact with the environment, or supporting professional groups directly involved in the fight against the virus.

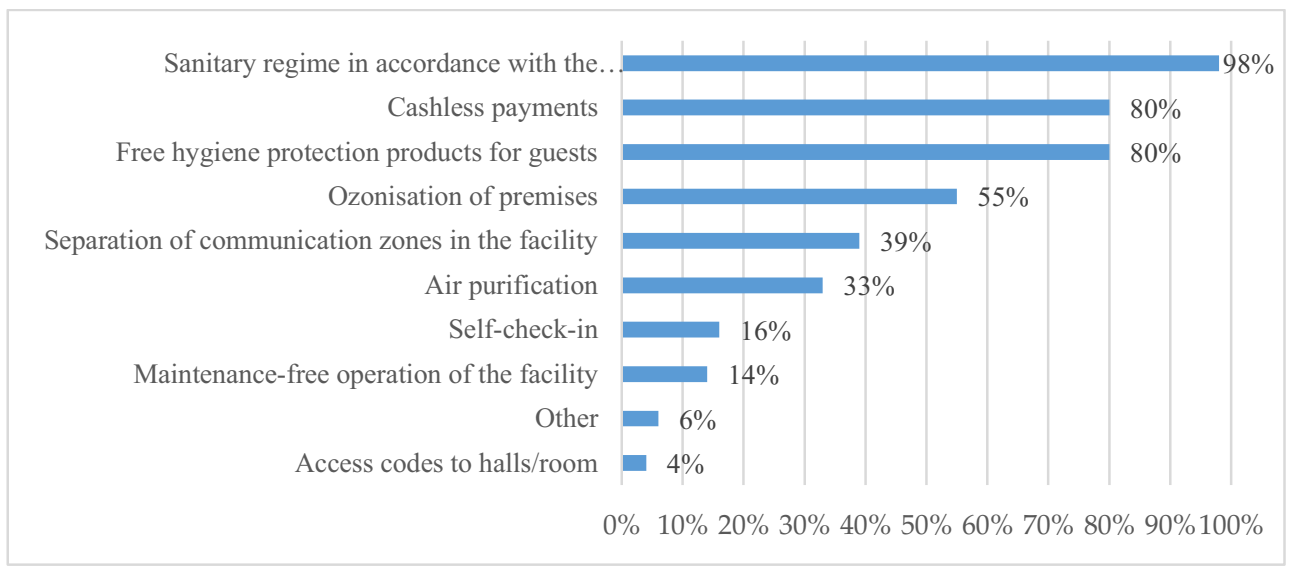

Fig. 2. Implemented measures in the surveyed hotel facilities during the COVID-19 pandemic.

As the respondents indicated, many solutions implemented during the pandemic will also be carried out in the facilities in the future, e.g., cashless payments, partially or completely maintenance-free check-in, sanitary procedures, videoconferences, attention to cost reduction, remote work, multi-functionality of employees, flexible schedules, new marketing strategies aimed at a different type of a customer or expanding restaurant catering. These indications allow for a discussion on the direction in which the hospitality industry may go in the future. This direction is not only to protect the entity during unplanned situations, such as a pandemic, but also to operate in an economical and, importantly, sustainable manner.

The survey was supplemented with an additional case study of a Polish hotel company, which consists of 9 hotel facilities and 3 holiday resorts in different parts of the country, 3 regional travel agents and 5 licensing offices. These are entities employing a total of about 250 employees, operating under a common brand and having a similar level of service standard. The network showed a 70\% decrease in turnover in 2020 as compared to 2019 . The largest declines were recorded in the area of accommodation services, but also in the area of hotel services, such as: catering services, rental of conference rooms and commercial space for business activities (e.g., a flower shop in a hotel or a hairdressing salon). In the surveyed enterprise, government and anti-crisis support, among others, exemptions from social security contributions of employees [35] subsidies of the Polish Development Fund (PFR), was used. However, it was indicated that this support allowed to cover $50 \%$ of the losses held. A number of activities and solutions were undertaken in the audited entity to protect jobs and remain on the market (Table 1).

Freezing the tourism economy during the COVID-19 pandemic created an opportunity to sustain its development in the future [38]. For this purpose, the authors attempted a theoretical discussion of how, in this difficult time, the facilities achieved their own goals and how they corresponded with the assumptions of sustainable development.

\section{Results and discussion}

The UN Sustainable Development Goals provide detailed guidelines, tasks and activities to be achieved by mankind. The hospitality industry is a space where many of them are 
successfully implemented, at the same time being an asset (including promotional) or a form of competitive advantage. Through appropriate behaviours and strategic actions, facilities can influence many different entities, starting from contractors, external stakeholders, employees and visitors, as well as the local community. The results of the research on case studies, observations and recommendations are included in Table 1.

Table 1. Implementation of the selected UN Sustainable Development Goals in the hospitality industry before and during the COVID-19 pandemic, including recommendations.

\begin{tabular}{|c|c|}
\hline \multicolumn{2}{|r|}{ The UN Sustainable Development Goals (UN SDG) } \\
\hline \multicolumn{2}{|r|}{ No poverty } \\
\hline \multicolumn{2}{|r|}{ Zero hunger } \\
\hline \multicolumn{2}{|r|}{ Good Health and well-being } \\
\hline $\begin{array}{c}\text { Examples before } \\
\text { the pandemic } \\
\text { (BP) }\end{array}$ & $\begin{array}{ll} & \text { providing jobs } \\
- & \text { promoting equality } \\
- & \text { cooperating with local farmers } \\
- & \text { supporting ecological food production } \\
- & \text { charity work } \\
\text { - } & \text { food waste prevention programmes } \\
- & \text { environmental protection for a high quality of life } \\
- & \text { promoting health and quality of life through an appropriate offer, but also } \\
& \text { a good example of the ecological functioning of the company (example: } \\
& \text { Villa Park MED \& SPA) [39], } \\
- & \text { having certificates (e.g. Green Globe [40]) }\end{array}$ \\
\hline $\begin{array}{l}\text { Examples during } \\
\text { the COVID-19 } \\
\text { pandemic } \\
\text { (DP) }\end{array}$ & $\begin{array}{ll}\text { - } & \text { struggle to keep jobs } \\
\text { - } & \text { mutual, local support (hotel - supplier, e.g., farmer) } \\
\text { - } & \text { limited occupancy, tantamount to lower production of e.g., waste, saving } \\
& \text { water, energy }\end{array}$ \\
\hline $\begin{array}{l}\text { Case study } \\
\text { (CS) }\end{array}$ & $\begin{array}{l}\text { all jobs were maintained during the pandemic } \\
\text { - } \text { support for local entrepreneurs by negotiating previously concluded } \\
\text { contracts and their implementation } \\
\text { - an ecological approach to reducing food waste (smorgasbord at specific } \\
\text { times and product restrictions) }\end{array}$ \\
\hline $\begin{array}{l}\text { Recommendatio } \\
\text { ns } \\
\text { for future } \\
\text { (RF) }\end{array}$ & 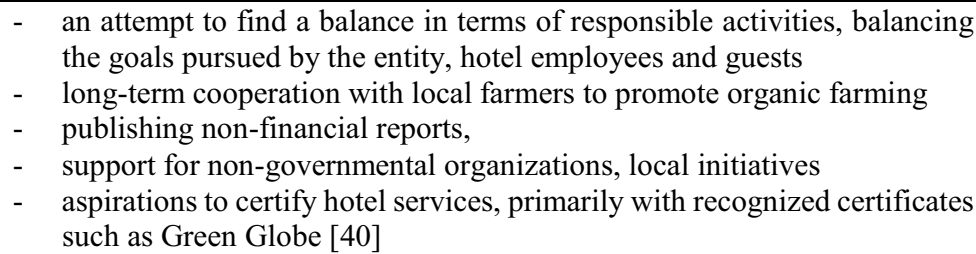 \\
\hline \multicolumn{2}{|r|}{ Quality education } \\
\hline BP & $\begin{array}{l}\text { - providing vocational education through apprenticeships, internships or } \\
\text { seasonal work (at the level of secondary, vocational and higher schools) } \\
\text { [39], } \\
\text { - meetings with students, lectures on the functioning of the hotel, etc. }\end{array}$ \\
\hline DP & $\begin{array}{l}\text { - during the pandemic, cooperation with schools, conducted in a hybrid } \\
\text { manner, adequate to the epidemic situation in the country } \\
\text { - in periods of minor restrictions, return to the implementation of, for } \\
\text { example, internships }\end{array}$ \\
\hline CS & $\begin{array}{l}\text { organizing internships, apprenticeship co-financed by the European } \\
\text { Union for young apprentices of the hotel and catering industry with an } \\
\text { additional aspect of innovative Covid-19 solutions for hotel guests (e.g., } \\
\text { the project entitled "The Best Professionals" co-financed by the European }\end{array}$ \\
\hline
\end{tabular}




\begin{tabular}{|c|c|}
\hline & $\begin{array}{l}\text { Social Fund under the Regional operational programme of the Lubuskie } \\
\text { Voivodeship for } 2014-2020 \text { ) }\end{array}$ \\
\hline $\mathbf{R F}$ & $\begin{array}{l}\text { - maintaining cooperation with schools of various levels, due to mutual } \\
\text { benefits } \\
\text { - in the event of limited financial possibilities of hiring new employees, } \\
\text { interns or apprentices may provide a temporary support for hotel facilities }\end{array}$ \\
\hline \multicolumn{2}{|r|}{ Gender Equality } \\
\hline \multicolumn{2}{|r|}{ Less inequality } \\
\hline BP & $\begin{array}{ll} & \text { promotion of facilities as safe places, regardless of gender or sexual } \\
\text { orientation (e.g. [41]) } \\
\text { - } & \text { anti-discrimination actions, protection of employee rights } \\
\text { - } & \text { gender equality } \\
\text { - } & \text { professional development of employees }\end{array}$ \\
\hline DP & $\begin{array}{l}\text { - taking care of all employees for their well-being and employment stability } \\
\text { by gaining government and anti-crisis support }\end{array}$ \\
\hline CS & $\begin{array}{l}\text { - } \text { no gender discrimination in employment at any job position } \\
\text { adaptation of workplaces for people with disabilities (e.g., external } \\
\text { driveway to the workplace, elevator, target workplace) } \\
\text { - professional development support for full-time employees (e.g., online } \\
\text { training for bakers, baristas, housekeepers; improving professional } \\
\text { qualifications) }\end{array}$ \\
\hline $\mathbf{R F}$ & $\begin{array}{ll}\text { - } & \text { a constant dialogue with employees, } \\
\text { - } & \text { creating multigenerational teams } \\
\text { - } & \text { a regular training for staff } \\
\text { - } & \text { publishing non-financial reports }\end{array}$ \\
\hline \multicolumn{2}{|r|}{ Clean water and sanitation } \\
\hline BP & $\begin{array}{ll}- & \text { responsible water management } \\
\text { - } & \text { reduction of water consumption as well as education in this area (staff and } \\
& \text { guests) } \\
\text { - } & \text { implemented "grey water" system (e.g. [42]) } \\
\text { - } & \text { use of certified products (e.g. Ecolabel [43]) }\end{array}$ \\
\hline DP & $\begin{array}{l}\text { - regardless of the need for limited functioning, the previously installed } \\
\text { water treatment systems and the method of its use were implemented } \\
\text { the systems installed allow the facilities to be independent (e.g., own } \\
\text { biological treatment plant) }\end{array}$ \\
\hline CS & $\begin{array}{l}\text { - using special filters with an air nozzle that reduces water consumption by } \\
\text { up to } 35 \%\end{array}$ \\
\hline RF & $\begin{array}{l}\text { - making investments in terms of responsibility for future generations } \\
\text { (including efficient use of water) } \\
\text { - publishing non-financial reports }\end{array}$ \\
\hline \multicolumn{2}{|r|}{ Affordable and clean energy } \\
\hline BP & 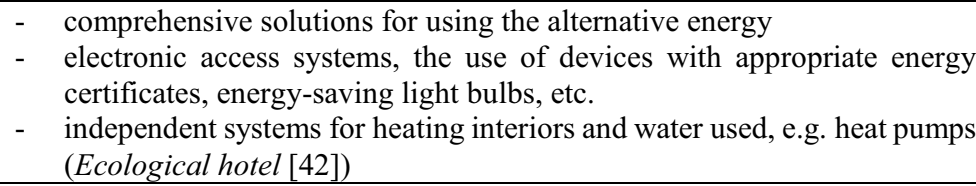 \\
\hline DP & $\begin{array}{l}\text { no impact of the pandemic on the abandonment of implemented systems } \\
\text { and solutions }\end{array}$ \\
\hline CS & $\begin{array}{l}\text { - using technology to reduce energy consumption through motion sensors } \\
\text { that automatically turn on the lights in the halls and corridors of the hotel } \\
\text { - using heat distribution centre energy as an alternative to air conditioning } \\
\text { by introducing natural condensation water to the radiators }\end{array}$ \\
\hline $\mathbf{R F}$ & $\begin{array}{l}\text { - installing ecological, alternative energy systems, which allows reducing } \\
\text { the negative social and environmental impact, as well as generate savings } \\
\text { - } \quad \text { modernization of applied technologies } \\
\text { - } \quad \text { publishing non-financial reports }\end{array}$ \\
\hline
\end{tabular}




\begin{tabular}{|c|c|}
\hline \multicolumn{2}{|r|}{ Decent work and economic growth } \\
\hline BP & $\begin{array}{ll}\text { - } & \text { providing and creating decent jobs, also with social amenities (e.g. [44]) } \\
\text { - } & \text { promoting creativity, entrepreneurship and innovation } \\
\text { - } & \text { decent work for women and men } \\
\text { - } & \text { promoting local culture in products, } \\
\text { - } & \text { supporting young people on the hotel market - a real impact on shaping a } \\
& \text { career path (e.g. [44]) }\end{array}$ \\
\hline DP & $\begin{array}{l}\text { - taking care of all employees, their well-being and employment stability } \\
\text { by obtaining government and anti-crisis support } \\
\text { - a dialogue with employees, compromise in terms of temporary solutions }\end{array}$ \\
\hline CS & 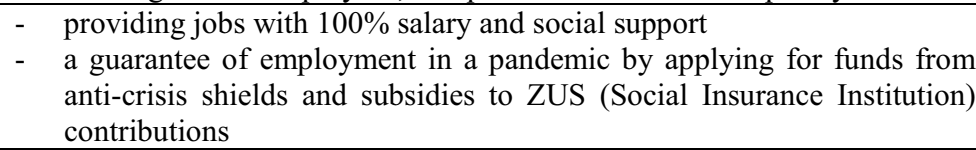 \\
\hline $\mathbf{R F}$ & $\begin{array}{l}\text { publishing non-financial reports in which all activities on the impact on } \\
\text { economic growth and the created conditions for decent employment are } \\
\text { described (this is a collection of good practices that can be an inspiration } \\
\text { and a model for other accommodation facilities) }\end{array}$ \\
\hline \multicolumn{2}{|r|}{ Industry, innovation and infrastructure } \\
\hline BP & $\begin{array}{ll}\text { - } & \text { a thoughtful location of the facility and arrangement of rooms } \\
\text { - } & \text { ecological construction technology and interior design (e.g. [45]) }\end{array}$ \\
\hline DP & $\begin{array}{l}\text { with total or partial restrictions in accommodation facilities, the time of } \\
\text { closing the facility was used for, e.g.: renovation, refurbishment or } \\
\text { reconstruction of facilities (depending on the availability of funds) }\end{array}$ \\
\hline CS & $\begin{array}{l}\text { - the period of limited or total inability to operate the hotel was used for } \\
\text { hygiene and sanitary activities } \\
\text { - renovations were carried out with the use of energy-saving materials, } \\
\text { aimed at minimizing electricity consumption in the future } \\
\text { - a modern approach to changing the image of facilities (family, safe, } \\
\text { accessible) } \\
\text { - infrastructure adapted to customer requirements (e.g., children's play } \\
\text { areas) }\end{array}$ \\
\hline $\mathbf{R F}$ & 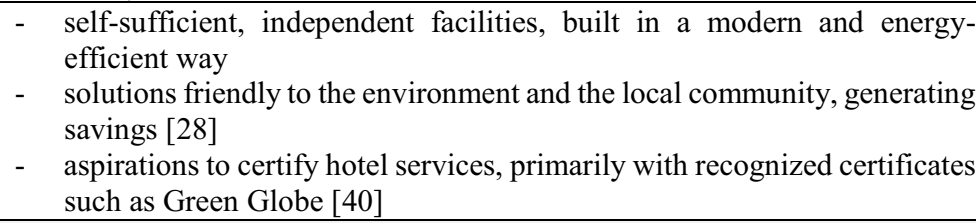 \\
\hline \multicolumn{2}{|r|}{ Sustainable cities and communities } \\
\hline BP & $\begin{array}{ll}\text { - } & \text { well-thought-out location of the facility } \\
\text { - } & \text { multi-entity cooperation (institutions, enterprises, local community) } \\
\text { - } & \text { cross-sectoral cooperation } \\
\text { - } & \text { initiative of the hospitality industry }\end{array}$ \\
\hline DP & $\begin{array}{ll}\text { - } & \text { pro-ecological initiatives in social media involving communities, } \\
\text { especially guests (e.g. Hotel Campanile [46] } \\
\text { - } \text { greater awareness of the need to care for the natural environment [39] } \\
\text { - } \quad \text { accommodation offer for medics } \\
\text { - hotel catering support for medical employees [47] }\end{array}$ \\
\hline CS & $\begin{array}{l}\text { - cooperation of hotel facilities with local commune and poviat authorities } \\
\text { as well as the Marshal's Office of the Wielkopolskie Voivodeship } \\
\text { - cooperation with local institutions (universities, Regional Cultural } \\
\text { Canters, local enterprises) }\end{array}$ \\
\hline $\mathbf{R F}$ & $\begin{array}{l}\text { - cooperation with the authorities of local government units } \\
\text { - a care on the part of the authorities in the field of spatial development } \\
\text { control (law and its enforcement) } \\
\text { - involvement in sustainable city and community strategies }\end{array}$ \\
\hline
\end{tabular}




\begin{tabular}{|c|c|}
\hline & $\begin{array}{ll}- & \text { initiating and supporting local initiatives } \\
\text { - } & \text { aspirations to certify hotel services, primarily with recognized certificates } \\
\text { such as Green Globe [40] }\end{array}$ \\
\hline \multicolumn{2}{|r|}{ Responsible consumption and production } \\
\hline \multicolumn{2}{|r|}{ Climate action, Life below water, Life on land } \\
\hline BP & $\begin{array}{ll} & \text { using, for example, local products in gastronomy } \\
\text { - } & \text { food production, which at the same time builds the brand of the place [39] } \\
\text { - } & \text { the growing awareness of guests regarding responsible consumption } \\
\text { forms the basis of expectations regarding accommodation facilities [30] }\end{array}$ \\
\hline DP & $\begin{array}{l}\text { - impact of the pandemic on higher environmental sensitivity in the light of } \\
\text { production processes } \\
\text { - } \text { production independence allowed reducing costs during the temporary } \\
\text { closure of the facility } \\
\text { - } \begin{array}{l}\text { stoppage of tourist traffic due to the pandemic is assessed as beneficial } \\
\text { for the climate and the environment }\end{array}\end{array}$ \\
\hline CS & $\begin{array}{l}\text { - minimizing the consumption of food products, in particular with meals } \\
\text { served in the form of a smorgasbord } \\
\text { informing guests about the number of kilos of products thrown away } \\
\text { during meals served in the form of a smorgasbord (educational initiative) }\end{array}$ \\
\hline $\mathbf{R F}$ & 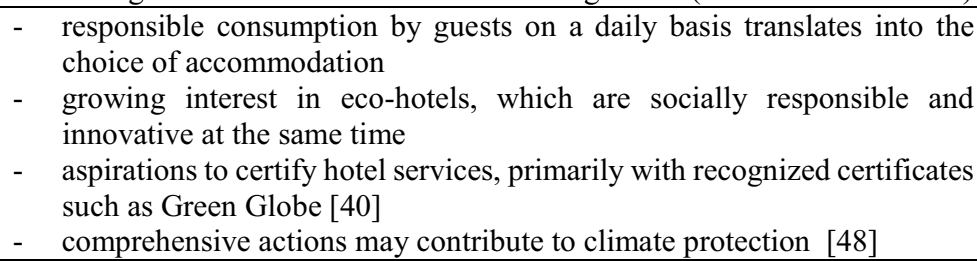 \\
\hline
\end{tabular}

Source: developed by the authors based on: [5], [50], [51], [22], [35], [40], [45],[46], [43].

The conducted secondary and primary research show that the implementation of the Sustainable Development Goals during the COVID-19 pandemic was not endangered, and it was even extended in social aspects. In the facility under study, the pandemic period allowed for the tightening of relations with contractors (mutual support and maintenance of previously concluded contracts), as well as wider openness to social initiatives. The period of restrictions on hotel facilities clearly contributed to a significant deterioration of the financial condition, however, in many cases, it made the facility managers open up to social initiatives and involvement in the fight against the virus. The currently observed phenomenon (third quarter of 2021) is the increased interest in the organization of family gatherings, such as weddings, due to concerns about the 4th wave of the coronavirus in Poland. This situation will temporarily improve the financial condition of the facilities, but it is difficult to determine what it will look like in the fourth quarter of 2021. Moreover, the surveyed facility notices changes in the structure of its own customers, with the enlargement of the segment of families with children, also due to government subsidies (Travel Voucher - note).

As shown in table 1, the implementation of the sustainable development goals in facilities generates a number of benefits, including self-reliance in many aspects, and thus independence and greater control of the negative impact of external factors (e.g., epidemics, pandemics). The authors of the considerations note that the more comprehensively hotel facilities implement the goals of the sustainable development concept, the greater the chance they have to return to the pre-pandemic state. Guests point to the growing interest in socially responsible, ecological and innovative facilities. Therefore, the recommendations will concern building comprehensive strategies for the development of the facility in the full range of environmental, social and economic sustainability.

\section{Limitations and future research}


It would be worthwhile to conduct future research in a comprehensive manner, examining the demand and supply of the hotel market in order to determine the common point of understanding and implementing the assumptions of sustainable development. The future intention of the researchers is a reliable and multifaceted look at the effects of the pandemic on the solutions implemented during its course and their compliance with the Sustainable Development Goals (UN SGDs). A limitation of the cited studies, especially regarding the supply in the hospitality industry, is the low level of survey feedback. The research presented in the article was conducted in the time of the pandemic, during which hoteliers expressed regret, dissatisfaction and helplessness in relation to the situation in which they found themselves. The biggest challenges in the second half of 2021 include survival on the market, achieving financial stability, maintaining the employment of qualified staff, or changing activities in the areas of management and marketing. The assessment of the return of the hospitality industry to the pre-pandemic state along with developing market survival practices in crisis will surely be a challenging research topic.

\section{Conclusions}

In the hospitality industry, sustainable development has clearly gained in importance in recent years. This is mainly due to the growing awareness of customers who, with such a large supply of accommodation places, pay more attention not only to the conditions and cost of accommodation, but also to the overall activity of the hotel. The contribution of a given facility to the broadly understood sustainable development is often a premise for its choice by customers who support these activities with their decision. Considering that some of these activities are difficult to verify for customers, hoteliers obviously should understand the concept and implement sustainable development tasks in a comprehensive manner, and not only in terms of individual applications (e.g., water saving).

A certain dissatisfaction in Poland is caused by the lack of a facility that at the moment would have the internationally recognized Green Globe certificate (as of 05.08.2021) [40]. The need for comprehensive regulation and unification of certain standards in Poland (including certification), as well as the need for a wider use of various incentives by the state, so that sustainable activity is more profitable for the industry, and its application does not result from altruistic motives, is already clearly visible in this aspect. The limitations resulting from the COVID-19 pandemic, whose impact on the industry can be clearly assessed as negative, at the same time often resulted in hotel looking for solutions to this situation and finding them, more or less consciously, in activities conducive to sustainable development, which gives hope for their more widespread use even after the pandemic.

In terms of recommended activities, apart from those which provide savings for the facility, it is certainly necessary to indicate the natural and environmental measures in a broad sense: from cooperation with local entities, supporting organic farming, to a certain independence in the field of food production. Important issues that have a huge impact on the entire organization are the staff, who will help to survive any crisis as long as they are provided for. An employee treated fairly, respected and appreciated may also show higher loyalty during a crisis.

Author Contributions: Conceptualization, D.P., O-T.K. and P.S.; methodology, D.P., O-T.K. and P.S formal analysis, D.P., O-T.K. and P.S.; investigation, D.P., O-T.K. and P.S.; resources, D.P., O-T.K. and P.S.; data curation, D.P., O-T.K. and P.S.; writing-original draft preparation, D.P., O-T.K. and P.S.; writing-review and editing, D.P., O-T.K. and P.S.; visualization D.P., O-T.K. and P.S.; supervision, D.P., O-T.K. and P.S.

Conflicts of Interest: The authors declare no conflict of interest. 


\section{References}

1. World Commission on Environment and Development. Our Common Future (Oxford University Press: Oxford, New York, 1987)

2. Diesendorf, M. Sustainability and Sustainable Development. Sustain. Corp. Chall. 21st Century, 2, 19-37 (2000)

3. Forum Odpowiedzialnego Biznesu. Zrównoważony rozwój https://odpowiedzialnybiznes.pl/artykuly/zrownowazony-rozwoj/ (2021)

4. ONZ. Agenda 2030 (rezolution) https://www.un.org.pl/agenda-2030-rezolucja (2021)

5. Sustainable Development Goals, http://www.un.org.pl/ (2021)

6. Trišić, I.; Štetić, S.; Privitera, D.; Petrović, M. D.; Maksin, M.; Vujović, S.; Jovanović, Z.; Kalinić, M. Perspectives on Sustainable Tourism Development in the Hotel Industry-A Case Study from Southern Europe. Sustainability, 13(10), 5563 (2021)

7. Dutescu, A.; Popa, A. F.; Ponorica, A. G. Sustainability of the Tourism Industry, Based on Financial Key Performance Indicators. Amfiteatru Econ. 16, 1048-1062 (2014)

8. Aboelmaged, M. Direct and Indirect Effects of Eco-Innovation, Environmental Orientation and Supplier Collaboration on Hotel Performance: An Empirical Study. $J$. Clean. Prod. 184, 537-549 (2018)

9. Barber, N. A. Profiling the Potential "Green" Hotel Guest: Who Are They and What Do They Want? J. Hosp. Tour. Res. 38(3), 361-387 (2014)

10. Laroche, M.; Bergeron, J.; Barbaro-Forleo, G. Targeting Consumers Who Are Willing to Pay More for Environmentally Friendly Products. J. Consum. Mark. 18, 503-520 (2001)

11. Peng, N.; Chen, A. Luxury Hotels Going Green - the Antecedents and Consequences of Consumer Hesitation. J. Sustain. Tour. 27(9), 1374-1392 (2019)

12. Rahman, I.; Park, J.; Chi, C. Consequences of "Greenwashing": Consumers' Reactions to Hotels' Green Initiatives. Int. J. Contemp. Hosp. Manag. 27 (2015)

13. Kim, Y.; Han, H. An Investigation of Green Hotel Customers' Decision Formation: Developing an Extended Model of the Theory of Planned Behavior. Int. J. Hosp. Manag. 29, 659-668 (2010)

14. Ponnapureddy, S.; Priskin, J.; Ohnmacht, T.; Vinzenz, F.; Wirth, W. The Influence of Trust Perceptions on German Tourists' Intention to Book a Sustainable Hotel: A New Approach to Analysing Marketing Information. J. Sustain. Tour. 25(7), 970-988 (2017)

15. Kim, Y. J.; Kim, W. G.; Choi, H.-M.; Phetvaroon, K. The Effect of Green Human Resource Management on Hotel Employees' Eco-Friendly Behavior and Environmental Performance. Int. J. Hosp. Manag. 76, 83-93 (2019)

16. Stroebel, M. Tourism and the Green Economy: Inspiring or Averting Change? Third World Q. 36(12), 2225-2243 (2015)

17. Ritchie, B. W. Chaos, Crises and Disasters: A Strategic Approach to Crisis Management in the Tourism Industry. Tour. Manag. 25(6), 669-683 (2004)

18. Jones, P.; Hillier, D.; Comfort, D. Sustainability in the Global Hotel Industry. Int. J. Contemp. Hosp. Manag. 26(1), 5-17 (2014)

19. Albino, V.; Ardito, L.; Dangelico, R. M.; Messeni Petruzzelli, A. Understanding the Development Trends of Low-Carbon Energy Technologies: A Patent Analysis. Appl. Energy, 135, 836-854 (2014) 
20. Grosbois, D. de. Corporate Social Responsibility Reporting by the Global Hotel Industry: Commitment, Initiatives and Performance. Int. J. Hosp. Manag. (2012), 31(3), 896-905 (2012)

21. Heung, V. C.; Fei, C.; Hu, C. Customer and Employee Perception of a Green Hotel-the Case of Five-Star Hotels in China. China Tour. Res. 2(3), 246-297 (2006)

22. Kapera I. Rozwój Zrównowazony w Hotelarstwie - Między Teorią a Praktyką w Polsce. , Turyzm” 2018, 282, 25-32 (2018)

23. Pizam, A. Green Hotels: A Fad, Ploy or Fact of Life? Int. J. Hosp. Manag. - INT J HOSP MANAG, 28, 1-1 (2009)

24. Chan, E. S. Green Marketing: Hotel Customers' Perspective. J. Travel Tour. Mark. 31(8), 915-936 (2014)

25. Ge, H.; Chen, S.; Chen, Y. International Alliance of Green Hotels to Reach Sustainable Competitive Advantages. Sustainability10 (2), 573 (2018)

26. Su, L.; Swanson, S. R. Perceived Corporate Social Responsibility's Impact on the Well-Being and Supportive Green Behaviors of Hotel Employees: The Mediating Role of the Employee-Corporate Relationship. Tour. Manag. 72, 437-450 (2019)

27. Garza, N. L. Effect of Ecolabels in Context on Perceived Sustainability. Or. State Univ., Undergraduate Honors College thesis. (2010)

28. Orfin-Tomaszewska K., Sidorkiewicz M. Shaping the Image of a Hotel Facility in the Context of Sustainable Development. Proc. 2018 VII Int. Sci. Conf. Determinants Reg. Dev. No 1 Pila 12-13 April 2018 260-274 (2018)

29. Garrigós-Simón, F. J.; Galdón-Salvador, J. L.; Gil-Pechuán, I. The Economic Sustainability of Tourism Growth through Leakage Calculation. Tour. Econ. 21(4), $721-739$ (2015)

30. Kapera, I.; Wszendybył-Skulska, E. Pro-Ecological Hotel Policies as Assessed by Guests. Turyzm/Tourism 27(2), 57-62 (2017)

31. Guevara, G. Open Letter From The World Travel \& Tourism Council (WTTC) https://wttc.org/News-Article/Open-letter-from-WTTC-to-Governments-from-WTTCand-the-Travel-Tourism-sector (2021)

32. Hoisington, A. 5 insights about how the COVID-19 pandemic will affect hotels https://www.hotelmanagement.net/own/roundup-5-insights-about-how-covid-19pandemic-will-affect-hotels (2021)

33. Jiang, Y.; Wen, J. Effects of COVID-19 on Hotel Marketing and Management: A Perspective Article. Int. J. Contemp. Hosp. Manag. 32(8), 2563-2573 (2020)

34. BOŚ, Analizy sektorowe https://www.bosbank.pl/korporacje/serwisekonomiczny/analizy-sektorowe (2021)

35. Efigence. Tarcza antykryzysowa - Grupa Polskiego Funduszu Rozwoju https://pfr.pl/tarcza.html (2021)

36. The Chamber of Commerce of the Polish Hotel Industry, https://www.ighp.pl/aktualnosci?section=hotelarstwo (2021)

37. Main page - ZUS http://www.zus.pl/ (2021)

38. Szromek, A. R.; Kruczek, Z.; Walas, B. Stakeholders' Attitudes towards Tools for Sustainable Tourism in Historical Cities. Tour. Recreat. Res. 1-13 (2021)

39. Lovrić, H.; Macan, T. T. Ekohotel przyszłością zrównoważonej turystyki? www.euractiv.pl (2020)

40. About Green Globe. Green Globe (2021) 
41. Hotele | GayPlaces.pl | Miejsca przyjazne LGBT+, Miejsca GayFriendly https://gayplaces.pl/type/hotel/Hotele-przyjazne\%20LGBT,\%20gay\%20friendly (2021)

42. Ecological Hotel - close to nature; https://www.uroczysko7stawow.pl/hotel/eko? (2021)

43. Everything about the EU Ecolabel https://www.pcbc.gov.pl/pl/uslugi/ecolabel/euecolabel (2021)

44. Orbis Hotel Group. Raport Społecznej Odpowiedzialności Za Rok 2018 (2018)

45. EKO Arłamów https://www.arlamow.pl/hotel-ekologiczny? (2021)

46. Louvre Hotels Group zaprasza gości do wspólnej troski o zrównoważony rozwój Aktualności - SaleBiznesowe.pl https://www.salebiznesowe.pl/aktualnosci/louvrehotels-group-zaprasza-gosci-do-wspolnej-troski-o-zrownowazony-rozwoj (2021)

47. gdansk.pl, -. Obiad dla medyka. Dzięki wsparciu dobrych ludzi są fundusze na blisko 4 tys. obiadów https://www.gdansk.pl/wiadomosci/obiad-dla-medyka-dzieki-panstwawsparciu-sa-fundusze-na-blisko-4-tys-obiadow,a, 169115 (2021)

48. Sinclair-Maragh, G. Climate Change and the Hospitality and Tourism Industry in Developing Countries. In Advances in Sustainability and Environmental Justice; Gonzalez-Perez, M. A., Leonard, L., Eds.; Emerald Group Publishing Limited; Vol. 19, pp 7-24. https://doi.org/10.1108/S2051-503020160000019001 (2016)

49. Cele Zrównoważonego Rozwoju http://www.un.org.pl/\# (2021)

50. Pakiet Dieta i Zdrowie. Villa Park Med \& SPA (2021)

51. Informator_koronawirus_wot.Pdf.(2020) 